\title{
APPLICATION REGARDING THE INDICATORS FOR THE COST-BENEFIT ANALYSES ON INFRASTRUCTURE PROJECTS
}

\author{
Professor PhD Teodor Hada, \\ Lecturer PhD Student Attila Tamas Szora \\ “1 Decembrie 1918” University, Alba Iulia, Romania
}

\begin{abstract}
The cost-effectiveness analyze is the effectiveness of some social programs analysis, using the systematic approach of the report between the benefits achieved (sum of positive consequences) and its costs (costs with resources) to whom are added the negative effects. The concept was developed in US in '50ty '60ty and was rapidly extended in Europe especially in relation to social policies.

Cost benefit analysis is a way of evaluating an investment (procurement) or project from the point of view of its economic efficiency. It consists, essentially, in comparing the total costs with the benefits expressed in financial terms. The costs must include costs with equipment procured, running costs (maintenance, training of users, expendable, etc) but also opportunity costs.

The benefits could be quantifiable (profit, reduction of losses), but it could be some benefits that are hardly quantifiable. For example, reduction of stress, improvement of reputation or improvement of employee's satisfaction that is hardly to have value in money.

The cost-effectiveness analyze is very important in the management of risks, especially in the stage of the control of risks. The decision of investing in measures for reducing the risks must be done only using the cost-effectiveness analyzes method. For example, the risk of loosing products because of a fire could be controlled by getting insurance or installing an automatic system for fire blow-out.

The costs with the two type of measures than the benefits obtained (depending on the risks analysis results) during of a year period are putted in balance and the best decision is taken.

We will make a practical example in case of a road infrastructure project: Rehabilitation of road and pedestrian artery.
\end{abstract}

In order to exemplify we considered an income generating investment in public infrastructure - pay road. The parameters of the investment are:

- investment value 793.693 USD

- implementing period 1 year

- analysis horizon 20 years

- actualization rate 5\%

- non-reimbursable percentage $100 \%$

- the foreseen incomes and spendings for the investments are:

\begin{tabular}{|c|c|c|c|c|c|c|c|c|c|c|c|c|c|c|c|c|c|c|c|c|}
\hline \multirow[b]{2}{*}{ Thousands USD } & \multicolumn{20}{|c|}{ Year } \\
\hline & 1 & 2 & 3 & 4 & 5 & 6 & 7 & 8 & 9 & 10 & 11 & 12 & 13 & 14 & 15 & 16 & 17 & 18 & 19 & 20 \\
\hline Sells & 20 & 48 & 55 & 70 & 103 & 110 & 115 & 121 & 122 & 125 & 125 & 128 & 128 & 122 & 117 & 109 & 105 & 105 & 103 & 102 \\
\hline Total incomes & 20 & 48 & 55 & 70 & 103 & 110 & 115 & 121 & 122 & 125 & 125 & 128 & 128 & 122 & 117 & 109 & 105 & 105 & 103 & 102 \\
\hline Total operational costs & 0 & 24 & 25 & 25 & 27 & 30 & 31 & 31 & 34 & 34 & 35 & 35 & 38 & 38 & 42 & 45 & 49 & 53 & 56 & 59 \\
\hline Total costs of investment & 794 & 0 & 0 & 0 & 0 & 0 & 0 & 0 & 0 & 0 & 0 & 0 & 0 & 0 & 0 & 0 & 0 & 0 & 0 & 0 \\
\hline Total costs & 794 & 24 & 25 & 25 & 27 & 30 & 31 & 31 & 34 & 34 & 35 & 35 & 38 & 38 & 42 & 45 & 49 & 53 & 56 & 59 \\
\hline Net financial flow & -774 & 24 & 30 & 45 & 76 & 80 & 84 & 90 & 88 & 91 & 90 & 93 & 90 & 84 & 75 & 64 & 56 & 52 & 47 & 43 \\
\hline
\end{tabular}




\section{Recalculation of the non-reimbursable financing:}

According to art. 55 of Regulation 1083/2006, the EU grant for the income generating projects is determined by establishing the calculation basis to which the approved percentages are applied. This calculation basis includes only eligible costs. Art. 55 (2) stipulates that: eligible spending can under no circumstances exceed the actualized value of the investment costs from which the net actualized income of the current activity is deducted, for the analyses horizon that corresponds to the investment. This applies to all projects, not only top major projects.

Art. 55 is applies to all projects that generate direct net income form operating (net income $=$ operating incomes - operating and maintenance spending). This does not apply to the following cases:

- the projects do not generate incomes (roads without toll, schools etc.)

- the projects generate incomes that do not cover operating and maintenance spending (they have no net incomes, for instance: some of the railroads projects)

- the projects are subject of the state aid.

Steps in determining the EU grant for 2007-2013:

1. Determining the total cost of the investment $=\sum$ eligible costs + ??? non-eligible costs

2. Determining the actualized cost of the investment $=\mathrm{C}$

3. Determining the net actualized income from the operation: $\mathrm{R}=$ actualized incomes from operating - operating spending and actualized maintenances (including amortization) + actualized residual value

4. Determining the rate (coefficient) of what is to be financed $r=(C-R) / C$

5. Determining the decision basis (eligible spending to which the approved co-financing rate for the respective priority axis from the CCE is applied):

$\mathrm{EC}=\sum$ eligible costs

Max. considered eligible costs $=\mathrm{DCE}=\mathrm{EC} * \mathrm{r}$

This way, the practical situation of the above mentioned example is as follows (thousands dollars):

Thousands dollars

\begin{tabular}{|l|r|}
\hline Cost of the investment & 794 \\
\hline Actualized cost of the investment $-\mathrm{C}$ (VANI) & 756 \\
\hline Net actualized income from operating - R & 302 \\
\hline $\mathrm{C}-\mathrm{R}$ & 454 \\
\hline $\mathrm{r}=(\mathrm{C}-\mathrm{R}) / \mathrm{C}$ (non reimbursable financial aid becomes 60\%) & 0,60 \\
\hline $\mathrm{G}\left(\mathrm{E}^{*} \mathrm{r}\right)$ & 476,70 \\
\hline
\end{tabular}

\section{Corrections based on some conversion factors}

This section deals with the introducing of conversion factors of the market prices into economic prices "shadow prices". Due to the distortions of imperfect competition, the financial prices do not reflect the real value of the entities considered in the financial analysis. Therefore the following correction factors of prices have been applied in the economic analysis:

The shadow price of the work:

It has been estimated that taxes and transfer within this component are situated at $65,25 \%$,

- contributions employer: $32,25 \%$

- contributions employee: $33 \%$

The final shadow price of work (SL) is 0.3475 . 
Services and goods used:

For this cost/benefices category the local market does not introduce considerable distortions (or these can not be objectively evaluated). That is why the conversion factor used here is the standard conversion factor of 0.9 .

\section{Te shadow price of currency exchange}

The proposed investment does not necessary need direct imports/exports of goods and services, that would imply currency exchange. That is why the conversion factor of the shadow price of the currency exchange (SF) is 1 .

The calculation of the standard conversion factor is detailed this way:

$$
\begin{aligned}
& \text { Total imports }(\mathrm{M}) \\
& \text { Total exports }(\mathrm{X}) \text { : } \\
& \text { Import taxes (tm): } \\
& \text { Export taxes (tx): }
\end{aligned}
$$

Mil. USD

0

Source: information from the National Institute for Statistics, web address: http://www.insse.ro/SDDS/default.asp\#Fiscal.

The computing formula for the standard conversion factor (SCF):

$$
\mathrm{SCF}=(\mathrm{M}+\mathrm{X}) /((\mathrm{M}+\mathrm{tm})+(\mathrm{X}-\mathrm{tx}))=\mathbf{0 , 8 9 9}
$$

The economical value of costs $(\mathrm{EV})$ is calculated with the formula: where:

F part in the currency exchange

SF shadow price of the currency exchange

$\mathrm{L}$ part of the market value in work

SL shadow price of work

O part of the local spending, minus work

$\mathrm{U}$ part of the spending with the machines

$\mathrm{T}$ part of the spending with transportation

The costs have been detailed into investment costs and operating costs.

Evaluation of the investment costs

\begin{tabular}{|l|r|r|r|}
\hline \multicolumn{1}{|c|}{ Category } & $(\%)$ Costs & $(\%)$ Total & Value (usd) \\
\hline $\mathrm{F}$ & & $0 \%$ & \\
\hline $\mathrm{L}$ & & $30 \%$ & $238.107,85$ \\
\hline 0 & & $15 \%$ & $119.053,93$ \\
\hline $\mathrm{U}$ & & $45 \%$ & $357.161,78$ \\
\hline $\mathrm{T}$ & & $10 \%$ & $79.369,28$ \\
\hline Total & & $\mathbf{1 0 0 \%}$ & $\mathbf{7 9 3 . 6 9 2 , 8 4}$ \\
\hline
\end{tabular}

$\mathrm{EV}=\mathrm{LXSL}+\mathrm{OXSCF}+\mathrm{UXSCF}+\mathrm{TXSCF}$

$\mathrm{EV}=0,3 \mathrm{X} 0,345+0,15 \mathrm{X} 0,899+0,45 \mathrm{X} 0,899+0,01 \mathrm{X} 0,899$

$\mathrm{EV}=0,006+0,116+0,746+0,017=0,7328$

The economic value (EV) of the investment costs is $73.28 \%$.

The social cost of the investment spending is: 


\begin{tabular}{|l|r|}
\hline \multicolumn{1}{|c|}{ Total costs of investment, usd } & $793.692,84$ \\
\hline Correction factor & $73,28 \%$ \\
\hline Corrected costs of investment & $581.618,11$ \\
\hline
\end{tabular}

\section{Determining the investment indicators}

1. The net actualized value (V.A.N.)

This method compares the initial spending $\left(\mathrm{I}_{0}\right)$ with the actual value of the expected cashflows (CF1, CF2, ... CFn) for the entire life period of the investment (n). The net cash-flow represents in this case the available flow degage after deducting the taxes.

$$
V A N=-I o+\sum_{p=1}^{n} C F_{p}(1+i)^{-p}
$$

where: $\mathrm{i}=$ actualization rate

With the help of this selection criteria those projects are considered to be rentable that have a positive net actual value. For a given actualization rate, the positive net actual value represents means that the net disponibilities flows debagged, capitalized with this rate, are superior to the investment spending that are capitalized (based on the same rate) during the period.

VAN - a value that results by deducting the actualized value of the foreseen costs of an investment from the actualized value of the foreseen benefices (economic actualized net value VNAE; net actualized financial value - VNAF)

The net actualized value of the investment is calculated using the following formula:

$$
V A N I=\sum_{t=0}^{T} \frac{X t}{(1+i)^{p}}=X o+\frac{X_{1}}{(1+i)}+\frac{X_{2}}{(1+i)^{2}}+\ldots .+\frac{X_{t}}{(1+i)^{P}}
$$

where:

$\mathrm{x}-$ the costs of the investment in the year $\mathrm{p}$, and $\mathrm{T}$ is the period of the investment $\mathrm{i}$ - actualization rate

This way: VANI $=794 /(1+5 \%)=756$

The net actualized value of the result is calculated using the following formula:

$$
V A N R=\sum_{t=0}^{T} \frac{R_{t}}{(1+i)^{t}}=X o+\frac{R_{1}}{(1+i)}+\frac{R_{2}}{(1+i)^{2}}+\ldots .+\frac{R_{T}}{(1+i)^{T}}
$$

where:

$\mathrm{Rt}$ - is the net income (the net of the operating costs) from the year $\mathrm{t}, \mathrm{i}=$ the actualization rate

\begin{tabular}{|c|c|c|c|c|c|c|c|c|c|c|c|c|c|c|c|c|c|c|c|c|}
\hline $\begin{array}{l}\text { Operational } \\
\text { income }\end{array}$ & 20 & 24 & 30 & 45 & 76 & 80 & 84 & 90 & 88 & 91 & 90 & 93 & 90 & 84 & 75 & 64 & 56 & 52 & 47 & 43 \\
\hline Amortization & 40 & 40 & 40 & 40 & 40 & 40 & 40 & 40 & 40 & 40 & 40 & 40 & 40 & 40 & 40 & 40 & 40 & 40 & 40 & 40 \\
\hline Net income & -20 & -16 & -10 & 5 & 36 & 40 & 44 & 50 & 48 & 51 & 50 & 53 & 50 & 44 & 35 & 24 & 16 & 12 & 7 & 3 \\
\hline
\end{tabular}

Determining the net actualized result from the operation $=$ operating actualized incomes operating and maintenance actualized spending (including amortization) 
This way: $\operatorname{VANR}=-20 /(1+5 \%)+-16 /(1+5 \%)^{2}+\ldots+3 /(1+5 \%)^{20}=302$

The net actualized financial value - VNAF is the following:

\begin{tabular}{|c|c|c|c|c|c|c|c|c|c|c|c|c|c|c|c|c|c|c|c|c|}
\hline Net financial flow & . -774 & 24 & 30 & 45 & 76 & 80 & 84 & 90 & 88 & 91 & 90 & 93 & 90 & 84 & 75 & 64 & 56 & 52 & & 43 \\
\hline $\begin{array}{l}\text { Net actualized financial value of } \\
\text { the investment (VNAF) }\end{array}$ & & & & & & & & & & 41 & & & & & & & & & & \\
\hline Note: discount rate for NPV = & $5,0 \%$ & & & & & & & & & & & & & & & & & & & \\
\hline
\end{tabular}

\section{Internal rentability rate (R.I.R.)}

The internal rentability rate represents that part of the composite interest that when used as actualisation rate (i) for the calculation of the actual value of the cash-flows and investments of the projects makes the cum of the actual value of the cash-flow to be equal with the sum of the actual value of the investment costs (practically V.A.N. $=0$ ).

R.I.R. = "i" (unknown), for which V.A.N. = 0, this means:

$$
I_{0}=\sum_{p=1}^{n} C F_{p}(1+i)^{-p}
$$

So, in order to determine the internal rentability rate for a project we have to determine the actualization rate for which the net actual value is 0 or towards 0 . This rate is the one for which the project is considered as being rentable and on the level of which the acceptance or rejection of the project depends. The internal rentability rate indicates actually the average rate of the interest for the entire economic life of the investment for the invested funds, after the progressive recovery of the capital. The great inconvenience of the use of the internal rentability rate can occur when for the same projects there are different internal rate, a result of the fact that the internal rentability rate is determined as the stem of a polynomial equation of degree " $n$ " $(n=$ economic life period of the investment). Actually, the multiple stems can only appear if the series of the net liquidity flows supports one or more sign changes. This case can appear especially when the investments have a long life and important maintenance and renewal spending are necessary during this period.

In order to estimate the internal rentability rate, the net actual value corresponding to the various actualization rates, randomly chosen, is calculated. Step by step the value is determined for which this actualization rate (i) leads to the canceling of the net actual value (V.A.N. $=0$ ). Finally, for an exact internal rentability rate the following relation is used:

$$
R I R=i_{\min }+\left(i_{\max }-i_{\min }\right) \frac{V A N_{(+)}}{V A N+\left|V A N_{(-)}\right|}
$$

Where: imin $=$ smaller actualization rate; imax $=$ bigger actualization rate

The admitted difference between $\mathrm{i}$-min and $\mathrm{i}$-max is of maximum 5 percentage points.

In order to be considered feasible, an investment project must contain the RIR level at least equal with the actualization rate.

In the proposed example the internal financial reantability rate is:

\begin{tabular}{|l|c|c|c|c|c|c|c|c|c|c|c|c|c|c|c|c|c|c|c|c|}
\hline Year & 1 & 2 & 3 & 4 & 5 & 6 & 7 & 8 & 9 & 10 & 11 & 12 & 13 & 14 & 15 & 16 & 17 & 18 & 19 & 20 \\
\hline Net financial flow & $\mathbf{- 7 7 4}$ & $\mathbf{2 4}$ & $\mathbf{3 0}$ & $\mathbf{4 5}$ & $\mathbf{7 6}$ & $\mathbf{8 0}$ & $\mathbf{8 4}$ & $\mathbf{9 0}$ & $\mathbf{8 8}$ & $\mathbf{9 1}$ & $\mathbf{9 0}$ & $\mathbf{9 3}$ & $\mathbf{9 0}$ & $\mathbf{8 4}$ & $\mathbf{7 5}$ & $\mathbf{6 4}$ & $\mathbf{5 6}$ & $\mathbf{5 2}$ & $\mathbf{4 7}$ & $\mathbf{4 3}$ \\
\hline
\end{tabular}




\begin{tabular}{|l|c|}
\cline { 2 - 2 } $\begin{array}{l}\text { Financial rentability rate of the } \\
\text { investrment (RIR-F) }\end{array}$ & $\mathbf{5 , 6 3 \%}$ \\
\hline Actualization rate & $\mathbf{5 \%}$ \\
\hline
\end{tabular}

In order to simplify the calculation for the calculation mode for RIR the Excel program, IRR function can be used, where

- Values: represents the annual values from the cash-flow

- Guess: actualization rate

\section{Reports between the total actualized incomes and the actualized total costs}

The incomes-costs analysis represents the fundamental concept of economic and financial evaluation of the investment projects. The expression and measurement of efficiency in investment projects are based on the comparison, on e way or another, of the average annual economic advantages integrated with the volume of the necessary costs of investments and operating costs, dimensioned through traditional methods, static or in systematic approach, considering the economic influence of time.

On the evaluation of the investment projects in the dynamic variant of the processes, since the beginning of the preparing of the decision a great deal of attention is paid to the calculation and analysis of the report incomes/costs on variants of projects and alternatives.

The various methods of comparison of incomes and costs have as a goal to establish the link between these two parameters of the project, which is very important in order to measure efficiency, but also from the point of view of the possibilities to ensure the necessary funding for the investment, especially those in currency, of the bigger costs of this or of other deficitary resources.

AS a general rule, the analysis incomes/costs is based on the evaluation of the report and absolute difference between the total actualized costs (Vta) and the total actualized costs represented through the engaged capital (Kta) for $n=0$.

$$
V_{t a}=\sum_{h=1}^{d+D} V_{h} \frac{1}{(1+i)^{h}}
$$

$$
K_{t a}=\sum_{h=1}^{d+D}\left(I_{h}+C_{h}\right) \frac{1}{(1+i)^{h}}
$$

In the statistical approach of the problems, this is for an actualization rate $i=0$, the net advantage of the project will be:

If $\mathrm{Vt}=\mathrm{Kt}$, respectively $\mathrm{Vta}=\mathrm{Kta}$, then

$$
\mathrm{ANta}=\mathrm{Vta}-\mathrm{Kta}
$$

$$
\begin{array}{ll}
\partial_{\mathrm{a}}=\frac{V_{t}}{K_{t}}=1 & \partial_{\mathrm{a}}=\frac{V_{t a}}{K_{t a}}=1
\end{array}
$$

where $\partial$ reprezents the report incomes - costs, what indicates that the investment project does not produce advantages, nor losses, thhis means the investor loses nothing.

When $\mathrm{Vt}<\mathrm{Kt}, \mathrm{Vta}<\mathrm{Kta}$ the report incomes - costs is sub-unitary. $\partial=<1 ; \partial=<1$.

$$
\partial_{\mathrm{a}}=\frac{V_{t}}{K_{t}}\left\langle 1 \quad \partial_{\mathrm{a}}=\frac{V_{t a}}{K_{t a}}<1\right.
$$

In this case the project produces losses; this means the project is inefficient and must be rejected. If $\mathrm{Vta}_{\mathrm{ta}} \mathrm{Kta}<1$, there is no sense in calculating the other indicators of the dinamic analysis of the investments of this project. Instead of investing in that project it is more efficient to invest the investment funds into other rentable projects, to keep them in the bank, with a certain interest, to buy stocks from other economic agents. 


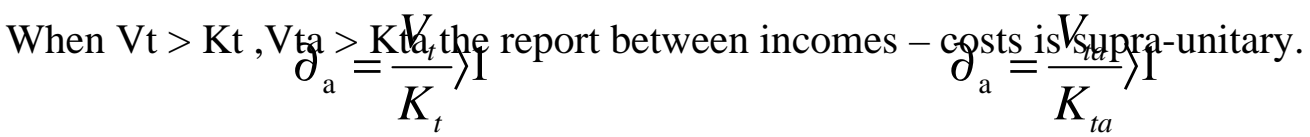

$\partial=>1 ; \partial=>1$, what indicates the fact that the project is efficient, acceptable and we can continue the dynamic analysis, with the help of other indicators of the investment's efficiency.

Considering that the analysis of this indicator refers to a long period of time, that $\mathrm{Vh}$ and $\mathrm{Ch}$ are foreseen values, in order to counter the possible perturbations and deformations of the $\partial$ indicator, because of the diminishing of the volume of the sold products, of the decrease in the selling price or the rising operating costs for the future, in order to keep a project $\partial$ has to be much bigger then 1 . The biger this indicator is, the more stabile and more concrete are the conclusions.

We must though underline that the report $V_{t a} / \mathrm{Kta}$ is sensitive to the increase of the actualization rates and therefore it is very important to correctly choose the actualization rate in order to avoid the acceptance of inefficient projects, or the rejection of rentable projects.

Between the dimension of the used actualization rate on one side and the value of the report incomes - costs as well as the absolute difference between incomes and costs, on the other side, the following relations are established:

- the smaller the size of the actualization rate, the bigger the value of the incomes - costs report and of the net advantage:

For $\mathrm{i}=0$,

$$
V_{t a}=V_{t}=\sum V_{h}, K_{a}=I_{t}+\sum C_{t}, \frac{V_{t a}}{K_{t a}}
$$

and $(\mathrm{Vta}-\mathrm{Kta})$ on maximal values;

- with the increase of the size of the actualization rate used in the calculations, the report Vta / Kta and the absolute size of the net economic advantage decreases, the report Vta / Kta may become sub-unitary, and (Vta-Kta) gains negative values.

These conclusions regarding the sensitivity of the report incomes - costs and of the net economic advantage given by the difference between incomes and costs at the size of the actualization rate have a special value for the fundamentation of the investment decisions, for choosing projects or variants of these. They also underline the necessity and utility of the dynamic approach of the economic and financial evaluation of investment projects and the importance of the correct choice of the size of the actualization rate.

Using a too small or to big actualization rate, uncorrelated with the activity's rentability, with the interest rate for the borrowed funds for the financing of the investment can lead to unjustified or wrong decisions.

It is considered that that variant or that project is the most efficient that ensures a maximal value of the indicator - the report between total actualized incomes and total actualized costs:

$$
\partial_{\mathrm{a}}=\frac{V_{t a}}{K_{t a}} \rightarrow \max
$$

In this conception, each investment alternative is characterized by an economic efficiency indicator with two components, or elements that are compared: Vta - as an integral economic effect or advantage on horizon $(\mathrm{d}+\mathrm{D})$, expressed in the actual value; Kta - as integral effort, of investment and operating, in the actual value, calculated on the same time horizon as the Vta. 
In the present case, the report total actualized incomes / total actualized costs is 1.04.

\begin{tabular}{|c|c|c|c|c|c|c|c|c|c|c|c|c|c|c|c|c|c|c|c|c|}
\hline \multirow[b]{2}{*}{ Thousends USD } & \multicolumn{20}{|c|}{ An } \\
\hline & 1 & 2 & 3 & 4 & 5 & 6 & 7 & 8 & 9 & 10 & 11 & 12 & 13 & 14 & 15 & 16 & 17 & 18 & 19 & 20 \\
\hline Sells & 20 & 48 & 55 & 70 & 103 & 110 & 115 & 121 & 122 & 125 & 125 & 128 & 128 & 122 & 117 & 109 & 105 & 105 & 103 & 102 \\
\hline Total incomes & 20 & 48 & 55 & 70 & 103 & 110 & 115 & 121 & 122 & 125 & 125 & 128 & 128 & 122 & 117 & 109 & 105 & 105 & 103 & 102 \\
\hline Total operational costs & 0 & 24 & 25 & 25 & 27 & 30 & 31 & 31 & 34 & 34 & 35 & 35 & 38 & 38 & 42 & 45 & 49 & 53 & 56 & 59 \\
\hline Total investment costs & 834 & 0 & 0 & 0 & 0 & 0 & 0 & 0 & 0 & 0 & 0 & 0 & 0 & 0 & 0 & 0 & 0 & 0 & 0 & 0 \\
\hline Total spendings & 834 & 24 & 25 & 25 & 27 & 30 & 31 & 31 & 34 & 34 & 35 & 35 & 38 & 38 & 42 & 45 & 49 & 53 & 56 & 59 \\
\hline
\end{tabular}

VAN incomes $=20 /(1+5 \%)+48 /(1+5 \%)^{2}+\ldots+102 /(1+5 \%)^{20}=11198.14$ USD

VAN spendings $=834 /(1+5 \%)+24 /(1+5 \%)^{2}+\ldots+59 /(1+5 \%)^{20}=1157.38$ USD

$\mathrm{V} / \mathrm{K} \quad=\quad 1.04$

\section{The economical analysis of the investment:}

In the above presented example the financial incomes and the spending of the investment project were considered. By the nature of the investment, pay road, collateral economic results are also obtained as follows: by the increase of the number of tourists as a result of ensuring the access into the area, the incomes of the community, based on the spending of the tourist, also increase. Without going into details, the estimation of the tourism benefices is presented as follows:

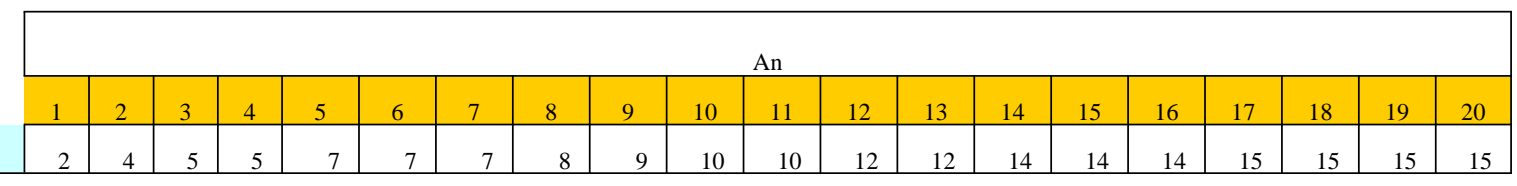

By adding the tourism incomes, the financial incomes obtained from the road tax, we determine the economic VAN and the economic RIR for the investment:

\begin{tabular}{|c|c|c|c|c|c|c|c|c|c|c|c|c|c|c|c|c|c|c|c|c|}
\hline \multirow[b]{2}{*}{ Thousands USD } & \multicolumn{20}{|c|}{ An } \\
\hline & 1 & 2 & 3 & 4 & 5 & 6 & 7 & 8 & 9 & 10 & 11 & 12 & 13 & 14 & 15 & 16 & 17 & 18 & 19 & 20 \\
\hline Sells & 20 & 48 & 55 & 70 & 103 & 110 & 115 & 121 & 122 & 125 & 125 & 128 & 128 & 122 & 117 & 109 & 105 & 105 & 103 & 102 \\
\hline Tourism incomes & 2 & 4 & 5 & 5 & 7 & 7 & 7 & 8 & 9 & 10 & 10 & 12 & 12 & 14 & 14 & 14 & 15 & 15 & 15 & 15 \\
\hline Total incomes & 22 & 52 & 60 & 75 & 110 & 117 & 122 & 129 & 131 & 135 & 135 & 140 & 140 & 136 & 131 & 123 & 120 & 120 & 118 & 117 \\
\hline Total operational costs & 0 & 24 & 25 & 25 & 27 & 30 & 31 & 31 & 34 & 34 & 35 & 35 & 38 & 38 & 42 & 45 & 49 & 53 & 56 & 59 \\
\hline Total investment costs & 794 & 0 & 0 & 0 & 0 & 0 & 0 & 0 & 0 & 0 & 0 & 0 & 0 & 0 & 0 & 0 & 0 & 0 & $\underline{0}$ & 0 \\
\hline Total spendings & 794 & 24 & 25 & 25 & 27 & 30 & 31 & 31 & 34 & 34 & 35 & 35 & 38 & 38 & 42 & 45 & 49 & 53 & 56 & 59 \\
\hline Net financial flow & -772 & 28 & 35 & 50 & 83 & 87 & 91 & 98 & 97 & 101 & 100 & 105 & 102 & 98 & 89 & 78 & 71 & 67 & 62 & 58 \\
\hline $\begin{array}{l}\text { Economic rentability } \\
\text { rate of the investment } \\
\text { (RIRE) }\end{array}$ & \multicolumn{20}{|c|}{$7,20 \%$} \\
\hline $\begin{array}{l}\text { Net actualized } \\
\text { economic value of } \\
\text { the investment } \\
\text { (VNAE) }\end{array}$ & \multicolumn{20}{|c|}{151} \\
\hline
\end{tabular}

VNAE $=-772 /(1+5 \%)+28 /(1+5 \%)^{2}+\ldots+58 /(1+5 \%)^{20}=151$ thousands USD

This way we conclude by presenting the main indicators of the investment:

VNAF $\quad=\quad 41$ thousand USD

VNAE $\quad=\quad 151$ thousand USD 


$\begin{array}{lll}\text { RIRF } & = & 5.63 \% \\ \text { RIRE } & = & 7.20 \% \\ \mathrm{~V} / \mathrm{K} & = & 1.04\end{array}$

The sensitivity analysis

The results of the financial analysis are based on a series of hypothesis for each variable. The value of the variables used in the analyses can suffer modifications and can affect the foreseen situation. This way, it is necessary to test the sensitivity of the actualized values of the key variables.

Hypothesis: the increase of the value of the investment with 5\%, determines the following indicators:

\begin{tabular}{|c|c|c|c|c|c|c|c|c|c|c|c|c|c|c|c|c|c|c|c|c|}
\hline \multirow[b]{2}{*}{ Mii USD } & \multicolumn{20}{|c|}{ An } \\
\hline & 1 & 2 & 3 & 4 & 5 & 6 & 7 & 8 & 9 & 10 & 11 & 12 & 13 & 14 & 15 & 16 & 17 & 18 & 19 & 20 \\
\hline Vanzari & 20 & 48 & 55 & 70 & 103 & 110 & 115 & 121 & 122 & 125 & 125 & 128 & 128 & 122 & 117 & 109 & 105 & 105 & 103 & 102 \\
\hline Venituri totale & 20 & 48 & 55 & 70 & 103 & 110 & 115 & 121 & 122 & 125 & 125 & 128 & 128 & 122 & 117 & 109 & 105 & 105 & 103 & 102 \\
\hline Costuri totale operationale & 0 & 24 & 25 & 25 & 27 & 30 & 31 & 31 & 34 & 34 & 35 & 35 & 38 & 38 & 42 & 45 & 49 & 53 & 56 & 59 \\
\hline Costuri totale ale investitiei & 834 & 0 & 0 & 0 & 0 & 0 & 0 & 0 & 0 & 0 & 0 & 0 & 0 & 0 & 0 & 0 & 0 & 0 & 0 & 0 \\
\hline Cheltuieli totale & 834 & 24 & 25 & 25 & 27 & 30 & 31 & 31 & 34 & 34 & 35 & 35 & 38 & 38 & 42 & 45 & 49 & 53 & 56 & 59 \\
\hline Flux financiar net & -814 & 24 & 30 & 45 & 76 & 80 & 84 & 90 & 88 & 91 & 90 & 93 & 90 & 84 & 75 & 64 & 56 & 52 & 47 & 43 \\
\hline $\begin{array}{l}\text { Rata rentabilitatii } \\
\text { financiare a investitiei } \\
\text { (RIR) }\end{array}$ & \multicolumn{20}{|c|}{$5,04 \%$} \\
\hline $\begin{array}{l}\text { Valoarea actualizata } \\
\text { neta financiara a } \\
\text { investitiei (VNAF) }\end{array}$ & \multicolumn{20}{|c|}{3} \\
\hline $\begin{array}{l}\text { Beneficiul / Rata } \\
\text { capitalului }\end{array}$ & \multicolumn{20}{|c|}{1,00} \\
\hline
\end{tabular}

An increase in the value of the investment with 5\% represents a critical barrier because the report $\mathrm{V} / \mathrm{K}=1$, VANF is of only 3 thousand USD and RIR $=5.04$, under the circumstances when the actualization rate used is of only $5 \%$.

As one can notice from the above presented situation, the level of all indicators specific to the public infrastructure projects (based on the financial and economic analysis) corresponds to the financing request from European funds for this type of investments. This social and economical arguments support exclusively the variant of realization of the Eu financed project.

\section{BILBIOGRAPHY:}

1. Moise Ioan Achim, Teodor Hada, Managementul si Finantarea Afacerilor, Editura Risoprint, Cluj Napoca, anul 2007

2. Coordonator Cristian Bisa, Elaborarea Studiilor de Fezabilitate si a Planurilor de Afaceri, Editura BMT Publishing House Bucuresti, anul 2005 